\title{
Field Application of Dilophospora alopecuri to Manage Annual Ryegrass Toxicity Caused by Rathayibacter toxicus
}

Martin J. Barbetti, School of Plant Biology, Faculty of Natural and Agricultural Sciences, The University of Western Australia, Nedlands, WA 6009 Australia; and Ian T. Riley, School of Agriculture and Wine, University of Adelaide, Waite Campus, PMB1, Glen Osmond, SA 5064 Australia

\begin{abstract}
Barbetti, M. J., and Riley, I. T. 2006. Field application of Dilophospora alopecuri to manage annual ryegrass toxicity caused by Rathayibacter toxicus. Plant Dis. 90:229-232.

Field experiments were conducted in three consecutive years to determine the effect of Dilophospora alopecuri inoculation on the incidence of galls with Rathayibacter toxicus in annual ryegrass (Lolium rigidum). $R$. toxicus is carried into the grass by the seed gall nematode, $A n$ guina funesta, and colonizes the ovules, displacing the nematodes, and producing the toxin responsible for annual ryegrass toxicity. Treatments included three types of $D$. alopecuri inoculum (naturally colonized ryegrass, cultures grown on sterilized wheat grain, and spore suspension) applied at different application rates and times. In the first year, naturally colonized ryegrass (30 $\left.\mathrm{kg} \mathrm{ha}^{-1}\right)$, applied 1 week after the break of season, colonized wheat grain $\left(150 \mathrm{~kg} \mathrm{ha}^{-1}\right)$ applied once at 1, 4, or 8 weeks or applied three times at 1, 4, and 8 weeks after the break of season, and spore suspension at heading, all significantly reduced the numbers of bacterially colonized galls (by 85 to $96 \%$ ). In the second and third years, inoculum was applied at various rates and times. There were no significant treatment effects in the second year. In the third year, colonized wheat $\left(450 \mathrm{~kg} \mathrm{ha}^{-1}\right)$ reduced the number of bacterially colonized galls by $73 \%$ and there was a significant negative relationship between inoculation rate of colonized wheat $\left(5.5\right.$ to $\left.450 \mathrm{~kg} \mathrm{ha}^{-1}\right)$ and the number of bacterially colonized galls $(r=0.86, P<0.01)$. D. alopecuri has potential as a biopesticide for the management of annual ryegrass toxicity, but efficacy could be highly variable depending upon season or site, and uneconomic application rates might be needed.
\end{abstract}

Additional keywords: ARGT, nematode galls

Annual ryegrass toxicity (ARGT) is often a fatal disease for livestock that graze annual ryegrass (Lolium rigidum Gaud.) containing corynetoxins (6). The corynetoxins are produced by Rathayibacter toxicus (Riley and Ophel) Sasaki $(2,10)$ an actinomycete (17), which is carried into the ryegrass inflorescence by the plantparasitic nematode Anguina funesta Price, Fisher, and Kerr $(1,9,15)$. The organisms associated with ARGT occur over about 4 million ha of farmland in Western Australia and a comparable area in South Australia (16). Although livestock losses are considerable, they were estimated to constitute only $5 \%$ of the total cost of ARGT, which was conservatively estimated at $\$ 16.5$ million per year in 1991 (16; no current estimates are available).

Strategies adopted by farmers to reduce the incidence of ARGT include various ryegrass control practices in crops, and heavy grazing or herbicide application plus grazing in pastures, both heavily reliant on

Corresponding author: M. J. Barbetti

E-mail: mbarbett@cyllene.uwa.edu.au

Accepted for publication 19 September 2005.

DOI: 10.1094/PD-90-0229

(C) 2006 The American Phytopathological Society a range of selective and nonselective herbicides (4). However, such measures have resulted in reduced carrying capacity and the enhanced development of ryegrass herbicide resistance $(5,13)$. The use of combinations of multiple herbicides or new herbicides can delay development of ryegrass herbicide resistance in the short term but increase the cost of ryegrass control dramatically in the long term. A more economical and sustainable approach for control of ARGT is needed.

The fungus Dilophospora alopecuri (Fr.:Fr.) Fr. (twist fungus) occurs naturally in some areas of both Western Australia and South Australia, where ARGT was once prevalent $(7,11)$. It was postulated that the fungus might be related to the decline of ARGT (3). Riley (11) reported the first quantitative evidence linking the decline in ARGT outbreaks and the abundance of the fungus in the field. However, D. alopecuri was limited to areas of southern Australia and absent from large areas where the risk of ARGT outbreaks was the greatest $(11,12)$.

Pot and field experiments and commercial-scale applications for biocontrol (G. Yan and I. T. Riley, unpublished data) demonstrated the capacity of $D$. alopecuri both to suppress $R$. toxicus bacterially colonized gall development and to establish and persist outside its natural range of occurrence. Solid materials are considered to be more likely to be suitable for commercial application for controlling ARGT than liquid forms of $D$. alopecuri inoculum for several reasons (18). First, D. alopecuri relies on a seed gall-forming nematode to enter ryegrass in the field (9). Second, without a host or suitable growth substrate, spores in liquid D. alopecuri inoculum would be expected to have only a very limited life span following field application. Third, the activity of $A$. funesta juveniles on the soil surface depends on the time of year (usually June [early winter] to September [early spring]) and rainfall events (8), presumably because $D$. alopecuri spores need to be present during one or more of the several episodes of invasion by $A$. funesta juveniles that can occur over the period conducive to activity (June to September). In the study reported in this article, although we focused on solid substrates of $D$. alopecuri inoculum, we also included liquid formulations as well for comparison.

This article reports the results of field experiments conducted during three consecutive years to test the efficacy of three types of D. alopecuri inocula (naturally colonized ryegrass residues, cultures grown on sterilized wheat grain, and spore suspensions) on nematode and bacterially colonized gall development in the year of application. For some treatments, responses to application timing and rate also were assessed.

\section{MATERIALS AND METHODS}

Sites. Three separate experiments were conducted. Experiments 1 and 2 were conducted on separate farms in close proximity to Corrigin $\left(32^{\circ} 19^{\prime} \mathrm{S}, 117^{\circ} 52^{\prime} \mathrm{E}\right)$ in 1987 and 1988, and experiment 3 was in close proximity to Tammin $\left(31^{\circ} 38^{\prime} \mathrm{S}\right.$, $117^{\circ} 29^{\prime} \mathrm{E}$ ) in 1989 . Corrigin and Tammin have Mediterranean climates with dry summers and a distinct beginning to the growing season with opening autumn rains. Both sites at Corrigin were ryegrassdominant pastures, naturally colonized with the ARGT causal organisms, that had been in pasture for the previous 2 years but were on different farms. The Tammin site was likewise an infested ryegrass pasture, but in a field that had grown a wheat crop in the previous year (the crop was heavily infested with toxic annual ryegrass). 
Inoculum. Five D. alopecuri isolates from naturally colonized ryegrass were used because isolates could vary genetically $(14,19)$. The isolates were separately subcultured to potato dextrose agar (PDA) and incubated at $20^{\circ} \mathrm{C}$ under a light bank containing four $40-\mathrm{W}$ cool white fluorescent tubes and one 40-W black light tube (Philips TL 40 W.8p RS F40 BLB) for a 12-h photoperiod each day for up to 21 days. To prepare the colonized wheat inoculum, five colonized PDA agar plugs of each isolate (4 $\mathrm{mm}$ in diameter) were used to inoculate $500-\mathrm{ml}$ conical flasks containing sterilized wheat seed. Sterilized wheat seed was prepared by soaking $100 \mathrm{~g}$ of seed overnight in distilled water in bottles; excess water then was drained and the wheat seed autoclaved at $121^{\circ} \mathrm{C}$ for $20 \mathrm{~min}$ on three consecutive days. Inoculated wheat seed were incubated at $20^{\circ} \mathrm{C}$ under the illumination described above for 6 weeks, with flasks shaken daily to facilitate uniform colonization of the wheat seed. At 28 days, the colonized wheat grain was harvested, air dried in a laminar flow, and then sealed in plastic bags and stored at $4^{\circ} \mathrm{C}$ for up to 3 weeks until used. The colonized wheat grain was applied at $150 \mathrm{~kg} \mathrm{ha}^{-1}$ in year 1 and at rates of 5.5 to $450 \mathrm{~kg} \mathrm{ha}^{-1}$ in years 2 and 3 . For the $D$. alopecuri spore inoculum applications, $100 \mathrm{~g}$ of colonized air-dried wheat inoculum was added to $400 \mathrm{ml}$ of sterile distilled water, shaken, and allowed to soak for 24 $\mathrm{h}$, then vigorously shaken again, the spore suspension filtered off through a triple layer of muslin cloth to remove colonized wheat grains, and the spore concentration adjusted to $1.75 \times 10^{7}$ (year 1 ), 1.25 to $2.4 \times$ $10^{6}$ (year 2 ), or 1.1 to $5.0 \times 10^{7}$ (year 3 ). In year 1 , the colonized wheat inoculum applied on 5 May was sampled (four grains per replication) on 5 May, 23 June, 21 July, and 4 August, surface sterilized for $30 \mathrm{~s}$ in $70 \%$ alcohol, air dried, and plated to PDA containing aureomycin hydrochloride at 15 $\mu \mathrm{g} / \mathrm{g}$ to check the viability of $D$. alopecuri. The fungus was recovered from $92 \%$ or more of seed tested and, on all occasions, produced an abundance of viable spores that readily germinated on PDA.
Experiment 1. Treatments included three inoculum types with application times for colonized wheat inoculum, applied following the opening rains (Table 1).

Plots were 2 by $2 \mathrm{~m}$ with bare fallow buffers $1 \mathrm{~m}$ wide (buffers kept bare by application of glyphosate as required). There were six replications arranged in a randomized block design.

Opening rains occurred on 24 April (21 $\mathrm{mm}$ ) with follow-up rains on 1 May (7 $\mathrm{mm}), 16$ May $(9 \mathrm{~mm})$, and 17 May (7 $\mathrm{mm})$. On 5 May, treatments 1,2 , and 5 were inoculated; on 26 May, treatments 3 and 5; and on 23 June, treatments 4 and 5. The naturally colonized ryegrass used in treatment 1 was harvested from a separate area on the same farm and was applied at a rate of $30 \mathrm{~kg} \mathrm{ha}^{-1}$. The first $D$. alopecuri spore inoculum application was made on 4 August was at a concentration of 625 liters $\mathrm{ha}^{-1}$ of $1.75 \times 10^{6}$ spores $/ \mathrm{ml}$. The second application on 20 August was at 625 liters $\mathrm{ha}^{-1}$ of $4.5 \times 10^{6}$ spores $/ \mathrm{ml}$. At the time of the first application, there was an average of about 20 heads per plot that were more than $20 \%$ emerged (mean of 10 counts of 1 by $1 \mathrm{~m}$ across 10 plots) and, at the second spore application, there was an average of 202 heads/plot that were more than $20 \%$ emerged (mean of 5 counts of 1 by $1 \mathrm{~m}$ across 5 plots) and approximately $0.4 \%$ of heads were flowering. The spore suspension was applied by handheld mister. The monthly rainfall totals for April, May, June, and July were $31,103,54$, and 36 $\mathrm{mm}$, respectively.

The percentage of heads showing typical symptoms of twist was assessed on 3 November by counting all heads per plot showing twist symptoms. By this stage, the density of ryegrass heads was 450 heads $/ \mathrm{m}^{2}$ (mean of 10 counts of quadrant size 150 by $300 \mathrm{~mm}$ ). On 18 November, plots were mown to ground level using a rotary lawnmower, the material collected, and a $10-\mathrm{g} /$ plot subsample taken and assessed for the number of nematode and bacterially colonized galls (for brevity referred to as bacterial galls) per gram of seed.
Experiment 2. Treatments included $D$. alopecuri-colonized wheat at five concentrations applied at 2 weeks; spores applied at 2 or 6 weeks, twice at head emergence; or no inoculum (Table 2).

Plots were 2 by $2 \mathrm{~m}$ with $1-\mathrm{m}$ bare ground buffers around all plots. Glyphosate (Monsanto) was applied as required to maintain buffers as bare ground. There were six replications arranged in a randomized block design.

Opening rains occurred across 21 April (4 mm), 27 April (6 mm), 28 April (17 $\mathrm{mm})$, and 29 April $(10 \mathrm{~mm})$. On 6 May, additional ryegrass seed at $20 \mathrm{~kg} \mathrm{ha}^{-1}$ was surface broadcast and lightly raked in to ensure a high ryegrass density in the plots. Treatments 2 to 7 then were applied on the same day (11 June). On 26 June, a mixture of terbutryn (Crop Care) at $425 \mathrm{ml}$ a.i. ha ${ }^{-1}$ and MCPA (Crop Care) at $300 \mathrm{ml}$ a.i. ha ${ }^{-1}$ was sprayed on plots to control capeweed (Arctotheca calendula (L.) Levyens). On 12 August, the first ryegrass heads were observed emerging and, hence, treatment 8 was applied. Treatment 8 was reapplied on 26 August when there were about three ryegrass heads $\mathrm{m}^{-2}$ emerged. Monthly rainfall totals for April, May, June, and July were $39,57,42$, and $60 \mathrm{~mm}$, respectively.

Twist assessment was conducted on 12 October and the pasture was harvested on 17 November for gall assessment, as for experiment 1 .

Experiment 3. Treatments included $D$. alopecuri-colonized wheat at five concentrations applied at 1 week; spores applied at 1 or 6 weeks, or three times at head emergence; or no inoculum (Table 3). Plots were 2 by $2 \mathrm{~m}$ with $2-\mathrm{m}$ bare ground buffers around all plots using a combination of rotary hoeing and application of glyphosate herbicide sprays. There were six replications arranged in a randomized block design.

Opening seasonal rains occurred on 21 April (12 mm), 22 April (3 mm), 25 April (1 mm), and 26 April (9 mm). On 27 April, treatments 1 to 6 inclusive were applied. There were further follow-up rains of 7 $\mathrm{mm}$ on 30 April, $1 \mathrm{~mm}$ on 1 May, and 25

Table 1. Effect of field application of inoculum of Dilophospora alopecuri in year 1 (experiment 1) as naturally colonized ryegrass, colonized wheat, or spore inoculum on the proportion of heads showing twist symptoms (3 November) and on the number of nematode and bacterial galls per gram of seed (18 November)

\begin{tabular}{|c|c|c|c|c|}
\hline Treatment no. & Inoculum & $\begin{array}{c}\text { Heads with twist } \\
(\%)^{\mathrm{a}}\end{array}$ & $\begin{array}{l}\text { Nematode galls } \\
\text { (no./g of seed) }\end{array}$ & $\begin{array}{r}\text { Bacterial galls } \\
\text { (no./g of seed) }\end{array}$ \\
\hline 1 & Control; no inoculum & $0.7(4.6)$ & 15.7 & 4.5 \\
\hline 2 & Natural ryegrass, $30 \mathrm{~kg} / \mathrm{ha}$, at 1 week & $1.6(7.1)$ & 6.0 & 0.1 \\
\hline 3 & Wheat, $150 \mathrm{~kg} / \mathrm{ha}$, at 1 week & $1.4(6.7)$ & 7.7 & 0.2 \\
\hline 4 & Wheat, $150 \mathrm{~kg} / \mathrm{ha}$, at 4 weeks & $0.9(5.5)$ & 7.3 & 0.6 \\
\hline 5 & Wheat, $150 \mathrm{~kg} / \mathrm{ha}$, at 8 weeks & $2.0(8.0)$ & 11.3 & 2.2 \\
\hline 6 & Wheat, $150 \mathrm{~kg} / \mathrm{ha}$, at 1,4 , and 8 weeks & $2.0(8.1)$ & 5.9 & 0.2 \\
\hline 7 & Spores, 625 liters/ha $\times 2$, at head emergence & $1.3(6.4)$ & 3.9 & 0.6 \\
\hline Means & ... & 1.4 & 8.3 & 1.2 \\
\hline Significance $(P<)$ & $\ldots$ & 0.05 & 0.05 & 0.05 \\
\hline $\mathrm{LSD}, P \leq 0.05^{\mathrm{b}}$ & $\ldots$ & $0.8(1.9)$ & 6.6 & 2.9 \\
\hline
\end{tabular}

\footnotetext{
a Arcsin transformed in parentheses.

${ }^{\mathrm{b}}$ Least significant difference.
} 
mm on 16 May. Treatment 7 was applied on 31 May. Urea fertilizer at $30 \mathrm{~kg} \mathrm{ha}^{-1}$ was top dressed over plots on 17 July. Treatment 8 was applied on 14 August when there was approximately 15 ryegrass heads $/ \mathrm{m}^{2}$ emerging. Two repeat applications of spore inoculum at the same concentration were made to treatment 8 plots on 22 and 28 August when there were 75 and 200 emerged ryegrass heads $/ \mathrm{m}^{2}$, respectively. Monthly rainfall totals for April, May, June, and July were 31, 53, 40, and $49 \mathrm{~mm}$, respectively.

On 6 November, plots were harvested as in experiment 1 for gall assessment.

Data analysis. Data were analyzed using the analysis of variance functions of GenStat (release 6.1, 6th ed.; Lawes Agricultural Trust, Rothamsted Experimental Station, Harpenden, Herts., UK). Significant differences among means were assessed by least significant difference (LSD; $P=0.05$ ) tests. Regression analysis was conducted to determine the relationship between rate of $D$. alopecuri colonized wheat inoculum and the numbers of nematode galls and bacterial galls in the first and third experiments; regression coefficients were tested for significance at $P=0.05$. The data for proportion of heads with twist symptoms for experiment 1 were skewed and normalized by arcsin transformation.

\section{RESULTS}

Experiment 1. All inoculation treatments (except wheat at week 8) significantly reduced the numbers of both normal nematode galls (by 51 to $62 \%$ ) and bacterial galls (by 85 to 96\%). Regression analysis indicated that there was no significant relationship between the proportion of heads with twist symptoms and the number of normal nematode $(r=-0.08$; not significant $[\mathrm{ns}])$ or bacterial $(r=-0.06$; ns) galls per gram of seed.

Application of ryegrass naturally colonized with $D$. alopecuri 1 week after the break of season and the colonized wheat inoculum (all timings except at 4 weeks) increased the incidence of twist compared with the uninoculated control (Table 1).
However, there was a high incidence of twist in the control treatment and this may have reduced the relative impact of the treatments applied compared with the control.

Experiment 2. Annual ryegrass development in the trial area was extremely variable. There were no treatment effects upon the incidence of normal nematode or bacterial galls or upon the percent heads with twist symptoms (Table 2). As in experiment 1 , there was a high incidence of twist in the control treatment and this may have been a factor in why differences between treatments and the control were not evident in this experiment. Year two seemed to be a poor year for gall formation.

Experiment 3. The highest rate of colonized wheat inoculum reduced the number of bacterial galls per gram of harvested material from 17.1 to 4.6 , a $73 \%$ reduction (Table 3). Treatments had no effect on the numbers of normal nematode galls. There was no significant relationship between colonized wheat inoculum levels and the numbers of normal nematode galls ( $r=$ -0.40 ; ns). However, there was a significant negative relationship between colonized wheat inoculum rates and the number of bacterial galls $(r=-0.86, P<0.01)$.

Table 3. Effect of application of Dilophospora alopecuri in year 3 (experiment 3) as colonized wheat or as spore inoculum on the number of nematode and bacterial galls per gram of harvested dry material $(6 \text { November })^{\mathrm{a}}$

\begin{tabular}{|c|c|c|c|}
\hline Treatment no. & Inoculum & $\begin{array}{l}\text { Nematode } \\
\text { galls (no./ } \\
\text { g of seed) }\end{array}$ & $\begin{array}{l}\text { Bacterial } \\
\text { galls (no./ } \\
\text { g of seed) }\end{array}$ \\
\hline 1 & Control; no inoculum & 11.4 & 17.1 \\
\hline 2 & Wheat, $5.5 \mathrm{~kg} / \mathrm{ha}$, at 1 week & 14.4 & 17.3 \\
\hline 3 & Wheat $16.7 \mathrm{~kg} / \mathrm{ha}$, at 1 week & 11.8 & 10.4 \\
\hline 4 & Wheat, $50 \mathrm{~kg} / \mathrm{ha}$, at 1 week & 10.0 & 13.4 \\
\hline 5 & Wheat, $150 \mathrm{~kg} / \mathrm{ha}$, at 1 week & 14.2 & 9.6 \\
\hline 6 & Wheat, $450 \mathrm{~kg} / \mathrm{ha}$, at 1 week & 10.3 & 4.6 \\
\hline 7 & Spores, 500 liters/ha, at 1 week & 13.7 & 15.4 \\
\hline 8 & Spores. 500 liters/ha, at 6 weeks & 10.3 & 10.8 \\
\hline 9 & Spores, 500 liters $/$ ha $\times 3$, at head emergence & 15.8 & 21.3 \\
\hline Means & $\ldots$ & 12.4 & 13.3 \\
\hline Significance $(P<)$ & $\ldots$ & ns & 0.01 \\
\hline $\mathrm{LSD}, P \leq 0.05^{\mathrm{b}}$ & $\ldots$ & $\ldots$ & 8.24 \\
\hline
\end{tabular}

${ }^{\mathrm{a}} \mathrm{ns}=$ Not significant.

${ }^{\mathrm{b}}$ Least significant difference.
It is noteworthy that the overall mean incidence of bacterial galls was particularly high in year 3 (13.3 galls/g of seed) compared with 1.21 and 1.5 galls/g of seed for years 1 and 2, respectively. There was only a very low incidence $(<0.1 \%$ of heads) and sporadic occurrence of twist symptoms observed across the treatments in this experiment.

\section{DISCUSSION}

In the first year, application of residues of ryegrass naturally colonized by $D$. alopecuri 1 week after the break of season or the colonized wheat inoculum at all application times (except wheat at week 8) or the spore suspension at heading all significantly reduced the numbers of bacterial galls (by 85 to $96 \%$ ). It is possible that some ryegrass seed, nematodes, or bacterial galls were applied along with ryegrass naturally colonized by $D$. alopecuri and it remains to be determined if the effectiveness of such natural inoculum is influenced by the presence or absence of ryegrass seed, nematodes, or bacterial galls. Of the 3 years of experiments, it is noteworthy that the incidence of bacterial gall production was greater in the third year in a situation where only a very low incidence of twist symptoms was observed. In the third

Table 2. Effect of application of Dilophospora alopecuri in year 2 (experiment 2) as colonized wheat or as spore inoculum on the proportion of heads with twist symptoms (12 October) and on the number of nematode and bacterial galls per gram of seed $(17 \text { November })^{\mathrm{a}}$

\begin{tabular}{|c|c|c|c|c|}
\hline Treatment no. & Inoculum & $\begin{array}{c}\text { Heads with twist } \\
(\%)\end{array}$ & $\begin{array}{l}\text { Nematode galls } \\
\text { (no./g of seed) }\end{array}$ & $\begin{array}{l}\text { Bacterial galls } \\
\text { (no./g of seed) }\end{array}$ \\
\hline 1 & Control; no inoculum & 2.8 & 1.0 & 0.3 \\
\hline 2 & Wheat, $5.5 \mathrm{~kg} / \mathrm{ha}$, at 2 weeks & 0.7 & 3.0 & 0.3 \\
\hline 3 & Wheat, $16.7 \mathrm{~kg} / \mathrm{ha}$, at 2 weeks & 6.2 & 2.7 & 1.3 \\
\hline 4 & Wheat, $50 \mathrm{~kg} / \mathrm{ha}$, at 2 weeks & 5.3 & 1.2 & 1.2 \\
\hline 5 & Wheat, $150 \mathrm{~kg} / \mathrm{ha}$, at 2 weeks & 1.8 & 0.5 & 0 \\
\hline 6 & Wheat, $450 \mathrm{~kg} / \mathrm{ha}$, at 2 weeks & 4.5 & 0.7 & 0 \\
\hline 7 & Spores, 500 liters/ha, at 2 weeks & 0.7 & 3.8 & 0.2 \\
\hline 8 & Spores, 500 liters/ha, at 6 weeks & 1.3 & 15.2 & 8.8 \\
\hline 9 & Spores, 500 liters $/$ ha $\times 2$, at head emergence & 6.8 & 2.5 & 1.5 \\
\hline Means & $\ldots$ & 3.3 & 3.4 & 1.5 \\
\hline Significance $(P<)$ & $\ldots$ & ns & $\mathrm{ns}$ & ns \\
\hline
\end{tabular}

${ }^{\mathrm{a}} \mathrm{ns}=$ Not significant. 
year, the highest rate of colonized wheat inoculum reduced the number of bacterial galls (by 73\%) and there was negative relationship between colonized wheat inoculum levels and the number of bacterial galls. This highlights the significant potential for using D. alopecuri for biocontrol of colonization of ryegrass by the ARGT bacterium, because $R$. toxicus is the prime target for effective biocontrol of ARGT. The lack of relationship between the proportion of heads with twist symptoms and the number of bacterial galls per gram of seed demonstrates that twist symptoms are not a reliable indicator of the impact of $D$. alopecuri upon formation of bacterial galls. The failure of $D$. alopecuri to reduce nematode or bacterial galls in the second year is an indication that seasonal or site differences, or the application of herbicide sprays, could significantly influence the outcome of application of D. alopecuri for biocontrol of bacterial galls. It also is possible that the high incidence of twist in the control treatment may be a further reason why differences between treatments and the control were not evident in this experiment. Any seasonal or site influences did not appear to relate to rainfall in our study, but still need further investigation, as do potential herbicide effects, if biocontrol is to be reliably successful across wide-ranging commercial field situations.

Although the nematodes are required for the transmission of the bacteria to the ryegrass florets, they have no direct involvement in ARGT (7). In the first year, application of residues of ryegrass naturally colonized by $D$. alopecuri 1 week after the break of season or the wheat inoculum at all application times except at 8 weeks, or the spore suspension at heading, all significantly reduced the numbers of nematode galls (by 51 to $62 \%$ ). Regression analysis indicated that there was no relationship between the proportion of heads with twist symptoms and the number of nematode galls per gram of seed, and is an indication that twist symptoms are not a reliable indicator of the impact of $D$. alopecuri upon nematode gall formation.

In our study, the application of a $D$. alopecuri spore suspension in the first year significantly reduced numbers of both nematode and bacterial galls. Success of spore inoculum in this instance was an indication that, as a biocontrol agent, $D$. alopecuri, in some situations, can be independent of an external nutrient supply and still successfully establish on floral parts and initiate colonization and subsequent direct or indirect competition. In the first year, it is likely that the application of spores at heading was because nematodes were still invading younger tillers at the time of application. However, the reason for the failure of the spore applications in the second and third years to significantly reduce either nematode or bacterial gall numbers was not evident. For the future, we believe that, in relation to selection of optimal strains for mass production of $D$. alopecuri for commercial biocontrol of ARGT, solid materials have the greatest potential as growth substrate for commercial application because a liquid form of $D$. alopecuri inoculum is considered less likely to be suitable for controlling ARGT for several reasons (17), as outlined earlier in this article.

In the field, D. alopecuri spores in naturally colonized ryegrass residues are released from pycnidia in association with rainfall, ensuring that spore release and the activities of nematode juveniles are synchronized by rainfall events. It is noteworthy, in the first year of our study, that the lowest numbers of bacterial galls were from either naturally colonized ryegrass or from artificially colonized wheat grain, indicating that inoculum grown on any suitable solid substrate would be likely to perform in a fashion similar to residues of ryegrass naturally colonized by $D$. alopecuri. It is important for any commercial application of solid D. alopecuri inoculum to be made before the invasion stage of the nematode, to ensure not only the establishment of the biocontrol agent but also that spores are available at critical times for attaching to nematodes so they can be carried into and colonize ryegrass. Although naturally colonized ryegrass residues may be suitable for treating small target areas on-farm, for large-scale biocontrol, wheat grain offers a substantial food base for the biocontrol agent and has greater potential for commercial applications.

Our study highlights the significant potential for using $D$. alopecuri as a biopesticide for the bacterium responsible for annual ryegrass toxicity. Although the efficacy could be highly variable with season or site and uneconomic application rates might be needed to ensure success, particularly in the year of application, our study demonstrates that artificial inoculum can be used to introduce the twist fungus into fields at risk as part of a longer-term control strategy to reduce the incidence of ARGT.

\section{ACKNOWLEDGMENTS}

This study was supported by Australian Wool Innovation Ltd. We thank W. Pickering and R. Skinner for technical support; V. Neiman, J. Stanton, and A. Brown for helpful discussions in relation to these studies; N. Short for meteorological data; and K. Sivasithamparam for critical review of this manuscript.

\section{LITERATURE CITED}

1. Bird, A. F., and McKay, A. C. 1987. Adhesion of conidia of the fungus Dilophospora alopecuri to the cuticle of the nematode
Anguina agrostis, the vector in annual ryegrass toxicity. Int. J. Parasitol. 17:1239-1247.

2. Bird, A. F., and Stynes, B.A. 1977. The morphology of a Corynebacterium sp. parasitic on annual ryegrass. Phytopathology 67:828 830 .

3. Brown, A. G. P., and Vogel, P. 1986. Annual ryegrass toxicity research update. J. Agric. West. Aust. 27(4th ser.):3-6.

4. Burdass, W. J. 1986. Control strategies for annual ryegrass toxicity. J. Agric. West. Aust. 27(4th ser.):710.

5. Burnet, M. W. M., Barr, A., and Powles, S.B. 1994. Chloroacetamide resistance in rigid ryegrass (Lolium rigidum). Weed Sci. 42:153-157.

6. Edgar, I. A., Frahn, J. L., Cockrum, P. A., Anderton, N., Jago, M. V., Culvenor, C. C. J., Jones, A. J. , Murray, K., and Shaw, K. J. 1982. Corynetoxins, causative agents of annual ryegrass toxicity; their identification as tunicamycin group antibiotics. J. Chem. Soc. Chem. Commun. 1982:222-224.

7. McKay, A. C. 1985. Investigations to develop methods to control the nematode associated with annual ryegrass toxicity. Ph.D. thesis, The University of Adelaide, Adelaide, SA, Australia.

8. McKay, A. C., Fisher, J. M., and Dube, A. J. 1981. Ecological field studies on Anguina funesta, the vector in annual ryegrass toxicity. Aust. J. Agric. Res. 32:917-927.

9. Price, P. C., Fisher, J. M., and Kerr, A. 1979. Annual ryegrass toxicity: parasitism of Lolium rigidum by a seed gall forming nematode ( $A n-$ guina sp.). Ann. Appl. Biol. 91:359-369.

10. Riley, I. T. 1987. Serological relationships between strains of coryneform bacteria responsible for annual ryegrass toxicity and other plant-pathogenic corynebacteria. Int. J. Syst. Bacteriol. 35:153-159.

11. Riley, I. T. 1994. Dilophospora alopecuri and decline in annual ryegrass toxicity in Western Australia. Aust. J. Agric. Res. 45:841-850.

12. Riley, I. T. 1996. Dilophospora alopecuri on Lolium rigidum and Holcus lanatus in southeastern Australia. Aust. Plant Pathol. 25:255259.

13. Riley, I. T., and Gill, G. S. 1994. Relationship between herbicide resistance in Lolium rigidum and populations of Anguina funesta, the nematode vector in annual ryegrass toxicity, Aust. J. Exp. Agric. 34:633-635.

14. Riley, I. T., Reardon T. B., and Bertozzi T. 1998. Allozyme analysis of Australian strains of Dilophospora alopecuri. Mycol. Res. 102:301-307.

15. Riley, I. T., Stanton, J. M., and Brown, A. G. P. 1993. Reliability of paddock sampling for the organisms (Anguina funesta and Clavibacter toxicus) responsible for annual ryegrass toxicity. Aust. J. Exp. Agric. 33:861-864.

16. Roberts, W. D., and Baxter, A. 1991. The surveillance of annual ryegrass toxicity in Western Australia, October 1990 to May 1991. West. Aust. Dep. Agric. Misc. Publ. No. 32/91.

17. Sasaki, J., Chijimatsu, M., and Suzuki, K. 1998. Taxonomic significance of 2,4diaminobutyric acid isomers in the cell wall peptidoglycan of actinomycetes and reclassification of Clavibacter toxicus as Rathayibacter toxicus comb. Nov. Int. J. Syst. Bacteriol. 48:403-410.

18. Yan, G., and Riley, I. T. 2003. Fermentation period, moisture content, and substrate effects on inoculum effectiveness of Dilophospora alopecuri: a biocontrol agent of annual ryegrass toxicity. Biol. Control 26:174-179.

19. Yan, G., and Riley, I. T. 2005. Variation in colonisation of Lolium rigidum by isolates of Dilophospora alopecuri, an antagonist of the causal organisms of annual ryegrass toxicity. Aust. J. Exp. Agric. 45:1157-1162. 